\title{
III. Observations upon the œconomy of several species of Hymenoptera found in a garden at Clapton
}

\section{A. Kennedy Esq.}

To cite this article: A. Kennedy Esq. (1838) III. Observations upon the œconomy of several species of Hymenoptera found in a garden at Clapton , Philosophical Magazine Series 3, 12:71-72, 14-18, DOI: $10.1080 / 14786443808649367$

To link to this article: http://dx.doi.org/10.1080/14786443808649367

曲 Published online: 01 Jun 2009.

Submit your article to this journal $[\pi$

Џll Article views: 3

Q View related articles $\llbracket$ 
the æther resists compression to be so great that in the motions producing light it may be regarded as incompressible, the differences $\Delta \xi$ vanish, and the last two of our general equations (3.) of vol. viii., p. 9, become the same as the equations (1.) of this paper.

The reason assigned by Mr. Kelland (vol. ix. p. 341.) why the displacements $\xi$ are insensible, or, in other words, why there is no vibration in the direction of transmission, cannot, I conceive, be the true one; because it implies a state of unstable equilibrium. (See Pratt's Mechanical Philosophy, art. 508.) I believe the ingenious Fresnel considered the true reason to be the one which we have just supposed.

III. Observations upon the OEconomy of several Species of Hymenoptera found in a Garden at Clapton. By A. KENNEDY, Esq. *

HAVING had leisure this spring and summer to devote more time than usual to my favourite pursuit, entomology, I have paid considerable attention to the œconomy of various insects inhabiting a summer-house in my father's grounds, made of the stumps of trees, and having a thatched roof, which has afforded me much amusement from the number of different species of Hymenoptera which nidificate either in the posts or thatch.

The following is a list of the insects I have observed, and I shall make a few remarks upon the œconomy of each species, some of the facts relating to which I believe have not before been recorded.

Fam. Diplolepide.

1. Cratomus megacephalus, $F$.

Fam. Sarygidx.

2. Sapyga 4-guttata, $F$.

Fam. Crabronide.

3. Trypoxylon figulus, Lat.

4. - clavicerum, St. $F$.

5. Crabro spinipectus, Shuck.?

6. Stigmus troglodytes, Van $L$.

7. Diodontus insignis, $\operatorname{Van} L$.

8. 2 gracilis, Curt.

9. ㄴ. corniger, Shuck.

10. Pemphredon lugubris, $F$.
11. Pemphredon morio, $\operatorname{Van} L$.

12. - unicolor, Lat.

13. Psen atratum, $P z$.

Fam. Vespidx.

14. Odynerus quadratus, Don.

15. - bidens, $L$.

Fam. Andrenidex.

16. Hylæus signatus, $P z$.

Fam. ApID.x.

17. Chelostoma florisomnis, $L$.

18. Osmia bicornis, $L$.

19. - spinulosa, $K$.

20. Heriades campanularum, $\boldsymbol{K}$.

1. Cratomus megacephalus, Fab.

I have observed four or five specimens of this insect settling

* Communicated by the Author. 
upon the posts of the summer-house, but I have not ascertained any thing of its œconomy.

2. Sapyga 4-guttata*, Fab.

The ceconomy of this insect, I believe, is not known. I have taken two or three specimens flying about the posts. The male is much rarer than the female.

\section{Trypoxylon figrlus $\dagger$, Lat.}

This insect entombs spiders for the supply of its young ones. I have often watched it carrying the spiders into holes in the posts, and also into straws in the thatch. On splitting open one of the latter I found a number of cells filled with spiders and separated from one another by partitions of clay. Between each cell, there was a space left of about a quarter of an inch, so that there were two partitions between each cell, and between the last cell and the outside. There was one egg in each cell attached to the abdomen of a spider near the bottom of the cell. The Trypoxylon sometimes buries very large spiders compared with its own size, so that it can hardly jam them into its hole.

I was one day much amused with a male, who when the female was absent often came, entered, and remained at the entrance with his antennæ just projecting as if he was keeping watch to keep out parasitical insects; and once when I placed my hand over the hole so as to prevent the female entering, after repeated attempts she flew away, and returned with the male as if to ask his advice respecting the obstruction to her nest.

The number of spiders in the cells of course differs according to their size, there sometimes being only two if very large, and sometimes as many as twelve or more if small. The Trypoxylon does not appear to be partial to any particular species. The female makes a buzzing noise when she is constructing the clay partitions. I believe the conomy of this insect has never been distinctly ascertained before.

\section{Trypoxylon clavicerum $\ddagger$, St. F.}

The habits of this insect are similar to those of T. figulus, only burying very small spiders, and not leaving any space between the cells. I believe that $\mathrm{Mr}$. Shuckard and another gentleman are the only persons who have taken it besides myself. Its œconomy has not been noticed before.

5. Crabro spinipectus, Shuck.?

The male of this insect is common about the posts of the summer-house, but $I$ have not been able to discover the female.

* Curt. Brit. Ent., p. $532 . \quad+$ Ibid. p. 652,

$\ddagger I b i d$. 


\section{Stigmus troglodytes, Van L.}

I have taken four or five females of this insect and one male. On the 22nd of July I saw a female enter a straw with its prey in its mouth, and on splitting the straw open I found a great many minute insects, which appeared to be the larvæ of a Thrips. I should think there must have been at least fifty in one cell. There were two cells, separated from one another by partitions which appeared to be made of the scrapings of the inside of the straw cemented together. I also noticed a female with its prey enter a hole in one of the posts. I do not think the aconomy of this insect has ever been noticed before.

\section{Diodontus insignis, Van L.}

The males of D. insignis were common about the summerhouse from the beginning of July to the end of the same month, but $I$ have not been able to find one female.

\section{Diodontus gracilis*, Curt.}

The female supplies its young with aphides, which I have noticed it take from the leaves of the ivy. It makes its cells in the straws of the thatch, and separates them by partitions made apparently of the same materials as those of D.corniger. I have not taken any males.

\section{Diodontus corniger, Shuck.}

The male of this insect I first took on the 3rd of July, and the female on the 8th. The females were tolerably common towards the end of the month, but I have only taken six or seven males. The female provides aphides for the food of its young, and it appears to take them from the holes of other insects. I have often watched it entering holes in the posts and returning with aphides to its own hole. It carried them one by one in its mouth; and what was very curious, in going from its own to the other hole it ran straight along the post, but in returning with an aphis, although the holes were not half a foot apart, it flew off some distance before it conveyed its prey home. No other insect appeared to inhabit the holes from which it took the aphides. The partitions between each cell are made of a sticky transparent substance laid over with small fibres of wood. I have watched the female closing the orifice with the same material. After she had completely closed it with the propolis she went into another hole, and returned with small fibres of wood, which she plastered over, and this when dry became hard and strong. The habits of this insect have not been noticed by any one else, and I believe Mr. Shuckard is the only person who has taken it before myself. 
10. Pemphredon lugubris, Fab.

I have watched this insect burrow into the wood and throw out the saw-dust. It appears to prefer decayed wood for making its cells, in which it deposits aphides.

11. Pemphredon Morio, Van L.

I am not quite certain whether I took this insect at the summer-house or not, but I think I did.

\section{Pemphredon unicolor*, Lat.}

The ceconomy of $P$. unicolor is, I believe, well known. I have taken it carrying an aphis, but have not examined its cells.

13. Psen atratum $\dagger, \mathrm{Pz}$.

This insect has been exceedingly numerous this year, using the straws in the thatch to deposit its prey in, in some of which I have counted as many as a hundred aphide. The partitions appear to be made of the scrapings of the inside of the straw cemented together. The egg is white and semitransparent, and is attached to the abdomen of an aphis near the bottom of the cell. The males first appeared the beginning of July, flying about the thatch and the neighbouring shrubs in thousands. They disappeared about the end of the month. The females did not become numerous until the 10th.

\section{Odynerus quadratus $\ddagger$, Don.}

This insect entombs small green caterpillars having sixteen feet; six pectoral, eight abdominal, and two anal. On cutting open a post where I saw the female enter with its prey, I found a tunnel of about four inches in length running parallel with the sides of the post, and divided into three or four cells by partitions of clay. In each of these cells were about ten caterpillars closely packed, and a long white egg attached to the side of the cell near the bottom.

I first noticed this insect the beginning of June, and it was abundant during the whole of that month.

\section{Odynerus bidens, Linn.}

I observed a female of Odynerus bidens burrowing into a post the beginning of July, and a day or two afterwards I captured her while conveying her prey, which appeared to be the larva of a Chrysomela. On opening the post the end of July I found a tunnel two inches in depth, divided into three cells by partitions of clay. In the first cell the Odynerus was in the pupa state, and in the two lower ones in that of larra. Each of the cells contained the remains of larvæ, and in one of them was a small dipterous insect quite perfect.

- Curt. Brit. Ent., pl. 632. † Ibid,, fol. $25 . \quad \ddagger$ Ibid., fol. 137.

Phịl. Mag. S. 3. Vol. 12. No. 71. Jan. 1838. D 
16. Hylceus signntus*, $\mathrm{Pz}$.

I noticed a female of this insect enter a straw in the thatch, and on splitting it open I found at the bottom a quantity of some sweet substance, which I suppose was honey. It smelt exactly like the leaves of Verbena triphylla; and what is remarkable, I have taken many of the insects which had the same snell themselves, particularly when crushed. Yet I cannot think that they obtained it from that plant as we have none in the garden.

\section{Chelostoma florisomnist, Linn.}

On the 5 th of June I watched this insect boring into one of the posts and throwing out the saw-dust with her hind legs. On the 6th she had finished boring and was collecting the pollen and honey to deposit her eggs in. I also watched her bringing small pellets of clay in her mouth to form the partitions. This continued until the 30th, when she closed the orifice with clay and small stones. There are generally eight or ten cells in the tunnels nearly filled with pollen, \&c.; and the egg, which is long, white and semitransparent, is deposited in the midst at the top. The males I took flying about the posts where the females nidificated.

\section{Osmia bicornis †, Linn.}

The œconomy of this bee seems nearly similar to that of the last. It is found about the same time, but the males appear some time before the females.

\section{Osmia spinulosa, Kirb.}

This bee forms a paste of pollen, \&c. for its young, apparently similar to bicornis, but the partitions are of a green colour, and seem to be made of clay and the parenchyma of leaves kneaded together.

20. Heriades campanularum $\S$, Kirb.

I have taken this insect settling upon the posts of the summer-house, but have not observed any thing of its œconomy. Upper Clapton, Aug. 22, 1837.

A. KenNedy.

IV. Observations on induced Electric Currents, with a Description of a Magnetic Contact-breaker. By Golding BI RD, F.L.S., F.G.S., \&c., Lecturer on Experimental Philosophy at Guy's Hospital, \&c.; in a Letter to Richard Phillips, Esq. F.R.S., \&.c. My DEAR Sir,

ONE of the most important of the very numerous discoveries of Dr. Faraday is undoubtedly that of electrodynamic

- Curt. Brit. Ent., fol. 373.

\$.Ibid., fol. 222 . 